\title{
Experimental manipulation of predation and food supply of arctic ground squirrels in the boreal forest
}

\author{
Andrea E. Byrom, Tim J. Karels, Charles J. Krebs, and Rudy Boonstra
}

\begin{abstract}
We examined whether arctic ground squirrel (Spermophilus parryii plesius) populations in northern boreal forest in the Yukon Territory, Canada, were limited by food, predators, or a combination of both, during the decline and low phases of a snowshoe hare cycle. From 1990 to 1995, populations were monitored in large-scale $\left(1 \mathrm{~km}^{2}\right) \mathrm{ex}^{-}$ perimental manipulations. Squirrels were studied on eight 9-ha grids: four unmanipulated control grids, two foodsupplemented grids, a predator-exclosure grid, and a predator-exclosure + food-supplemented grid. Population density was measured on all grids by livetrapping and active-season survival was measured using radiotelemetry. Population densities were lowest in 1992 and 1993 (2 years after the snowshoe hare population decline). Rates of population change were negative from 1991 to 1993, when predation pressure was most intense after the snowshoe hare decline, and positive from 1993 to 1995, when hares and predators were at low densities. Predation accounted for 125 of 130 mortalities (96\%) of radio-collared squirrels. Adult survival was significantly lower in 1992 and 1993 than in 1994 and 1995, and was a strong predictor of annual rates of population change in arctic ground squirrels. Treatments were ranked as follows in their effect on adult survival: predator exclosure + food-supplemented > food-supplemented > predator exclosure > controls. Juvenile survival was lowest in 1992, and food addition and predator removal separately increased juvenile survival. On average, predator exclusion increased population densities twofold, food supplementation increased densities fourfold, and food supplementation and predator removal together increased densities 10-fold. We conclude that food and predation interact to limit arctic ground squirrel populations in the boreal forest during the decline and low phases of the snowshoe hare cycle. The snowshoe hare cycle may indirectly create a lagged secondary fluctuation in arctic ground squirrel populations through shared cyclic predators.
\end{abstract}

Résumé : Nous avons tenté de déterminer si les populations du Spermophile arctique du nord (Spermophilus parryii plesius) de la forêt boréale, au Yukon, Canada, sont régies par la nourriture, par les prédateurs ou par une combinaison des deux variables durant les phases de déclin et de faible densité du cycle du Lièvre d'Amérique. De 1990 à 1995 , les populations ont été suivies au cours de manipulations expérimentales à grande échelle $\left(1 \mathrm{~km}^{2}\right)$. Les spermophiles ont été étudiés en huit parcelles de 9 ha : quatre parcelles témoins non manipulées, deux parcelles recevant de la nourriture additionnelle, une parcelle excluant les prédateurs et une parcelle sans prédateurs mais avec addition de nourriture additionnelle. La densité des populations mesuré dans toutes les parcelles par capture d'animaux vivants, et la survie au cours de la saison d'activité, par radio-télémétrie. C'est en 1992 et 1993 que les densités de population ont été le plus faibles ( 2 ans après le déclin des populations de lièvres). Les taux de changement dans les populations ont été négatifs de 1991 à 1993, alors que la pression de prédation était le plus intense après le déclin des populations de lièvres, et positifs de 1993 à 1995, durant les périodes de densité faible aussi bien chez les prédateurs que chez les lièvres. La prédation a été responsable de 125 des 130 cas de mortalité (96\%) des spermophiles porteurs d'émetteurs. La survie des adultes a été significativement plus faible en 1992 et 1993 qu'en 1994 ou 1995, et cette variable s'est avérée un bon indicateur des taux annuels de changement dans les populations de Spermophiles arctiques. Les traitements peuvent être classifiés dans l'ordre suivant d'après leurs effets sur la survie des adultes : exclusion des prédateurs + addition de nourriture additionnelle > nourriture additionnelle > exclusion des prédateurs > témoins. La survie chez les juvéniles a été minimale en 1992 et l'addition de nourriture et le retrait des prédateurs considérés séparément augmentaient la survie chez ce groupe. En moyenne, l'exclusion des prédateurs aboutissait à une augmentation de la densité de la population par un facteur de 2, l'addition de nourriture l'augmentait par un facteur de 4, et les deux ensemble l'augmentaient par un facteur de 10. Nous concluons que l'interaction de la nourriture et de la prédation limite les

Received October 27, 1999. Accepted March 2, 2000.

A.E. Byrom ${ }^{1}$ and C.J. Krebs. Department of Zoology, The University of British Columbia, 6270 University Boulevard, Vancouver, BC V6T 1Z4, Canada.

T.J. Karels and R. Boonstra. Division of Life Sciences, University of Toronto at Scarborough, 1265 Military Trail, Scarborough, ON M1C 1A4, Canada.

${ }^{1}$ Author to whom all correspondence should be sent at the following address: Landcare Research, P.O. Box 69, Lincoln,

New Zealand (e-mail: ByromA@landcare.cri.nz). 
populations de spermophiles dans la forêt boréale durant le déclin et les périodes de densité faible des Lièvres d'Amérique. Le cycle des lièvres peut indirectement entraîner une période tardive de fluctuations secondaires chez les populations de Spermophiles arctiques car lièvres et spermophiles sont exposés aux mêmes prédateurs cycliques.

[Traduit par la Rédaction]

\section{Introduction}

External factors that limit the growth of animal populations, such as predation and food supply, have received considerable attention from ecologists (Elton 1927; Andrewartha and Birch 1954; Lack 1954; Errington 1967; Boutin 1990; Crawley 1992). Predators frequently limit and sometimes regulate prey populations (Erlinge et al. 1984; Kidd and Lewis 1987; Sinclair 1989), and food supplementation has dramatic effects on population densities, home-range size, recruitment, reproduction, and immigration in small-mammal populations (Gilbert and Krebs 1981; Taitt and Krebs 1981; Mares et al. 1982; Boutin 1990; Klenner and Krebs 1991). In addition, recent theoretical research (McNamara and Houston 1987; Lima and Dill 1990; Abrams 1994, 1999) and empirical evidence (e.g., Desy and Batzli 1989; Desy et al. 1990; Dickman 1992; Hughes and Ward 1993; Hughes et al. 1994; Hik 1995; Krebs et al. 1995) suggest that external factors, such as food and predation, interact to limit populations. Few studies, however, have attempted large-scale (i.e., several hectares) experimental manipulation of external limiting factors (Crawley 1992; Carpenter et al. 1995). In this paper, we present results from large-scale $\left(1 \mathrm{~km}^{2}\right)$ experimental manipulations designed to determine whether arctic ground squirrels (Spermophilus parryii plesius) are limited by predation, food, or an interaction between predation and food in a boreal-forest community with a dominant cyclic herbivore, the snowshoe hare (Lepus americanus).

In the North American boreal forest, snowshoe hare populations show regular cyclic fluctuations with a period of 811 years and up to a 100-fold change in amplitude (Elton and Nicholson 1942; Keith et al. 1977; Boutin et al. 1986; Krebs et al. 1986; Keith 1990). The main predator species resident in the boreal forest are lynx (Lynx canadensis), coyotes (Canis latrans), goshawks (Accipiter gentilis), and great horned owls (Bubo virginianus). In summer, migratory raptors, such as red-tailed hawks (Buteo jamaicensis), migrate to the Yukon to breed. Arctic ground squirrels are commonly found in arctic and alpine tundra habitats in Canada and Alaska (Carl 1971; Green 1977) but part of their range includes the northwestern boreal forests (Banfield 1974; McLean 1985), in which they are the third most abundant herbivore after snowshoe hares and red squirrels (Tamiasciurus hudsonicus) (Boutin et al. 1995). They hibernate in winter and are thus unavailable to predators for about 8 months of the year. During the summer months, arctic ground squirrels may become an "alternative prey" (Angelstam et al. 1984), as snowshoe hares become increasingly scarce during the decline and low phases of their cycle. Thus arctic ground squirrels provide a pulse of biomass during summer, following a period of potential food shortage for winter predators. The effects of predation and food supply on the demography of this seasonally abundant prey species as a consequence of the cyclic fluctuation in snowshoe hares are not well-documented.
Predation has been suggested as a factor limiting population growth for several species of ground-dwelling sciurids (Spermophilus spp.) (Michener and Michener 1977; Michener 1979; Schmutz et al. 1979; Erlien and Tester 1984; Schmutz and Hungle 1989; Elliott and Guetig 1990; Murie 1992). Ground squirrel populations have also responded to food supplementation (e.g., Columbian ground squirrels (Spermophilus columbianus), Dobson and Kjelgaard 1985a, 1985b; Dobson 1995; arctic ground squirrels, Green 1977; Hubbs and Boonstra 1997). However, rarely have the interactive effects of food and predation on arctic ground squirrel populations been examined (Karels et al. 2000). In this paper, we focus on the effects of predation and food supply on population density, adult and juvenile survival, and population growth rates of arctic ground squirrels from 1990 to 1995 . We present new results for the period 1993-1995 and also incorporate some earlier results (1990-1992), reported elsewhere by Hubbs and Boonstra (1997), to summarize trends in arctic ground squirrel populations during the peak, decline, and low phases of a snowshoe hare cycle (1990-1995). Hubbs and Boonstra (1997) examined the effects of predation and food on arctic ground squirrel populations during the early decline phase of the snowshoe hare cycle; among-treatment effects indicated that food was the major factor limiting ground squirrel populations, whereas among-year effects clearly indicated that predation must have accounted for major differences in adult survival during this time. Karels et al. (2000) found that food supplementation increased adult and juvenile growth rates, body condition, and reproduction, and possibly interacted with predation to affect population densities of arctic ground squirrels in the low phase of the snowshoe hare cycle.

We tested three alternative hypotheses to explain changes in arctic ground squirrel population densities and survival in the Canadian boreal forest during the decline and low phases of the snowshoe hare cycle: (1) squirrel populations are limited by predators ("top-down" hypothesis), (2) squirrel populations are limited by food ("bottom-up" hypothesis), and (3) squirrel populations are limited by both food and predation ("interaction" hypothesis). These hypotheses were tested by removing predators, adding supplemental food, and removing predators and adding food together in a factorial design. We predicted that, if predation alone limited arctic ground squirrel populations, survival and population density would be highest on areas where predators were excluded (irrespective of food availability) and, as predator numbers declined after the peak and decline in snowshoe hare numbers, population density and survival of arctic ground squirrels would increase. If food alone limited arctic ground squirrel populations, population density and survival would be highest on food-supplemented areas (irrespective of predation), and would not necessarily decline after the peak and decline in snowshoe hare populations. Finally, if the interaction hypothesis was correct, arctic ground squirrel survival and population 
Fig. 1. Location of the study area in the southwestern Yukon Territory, Canada, and the spatial arrangement of the experimental-treatment and control grids.

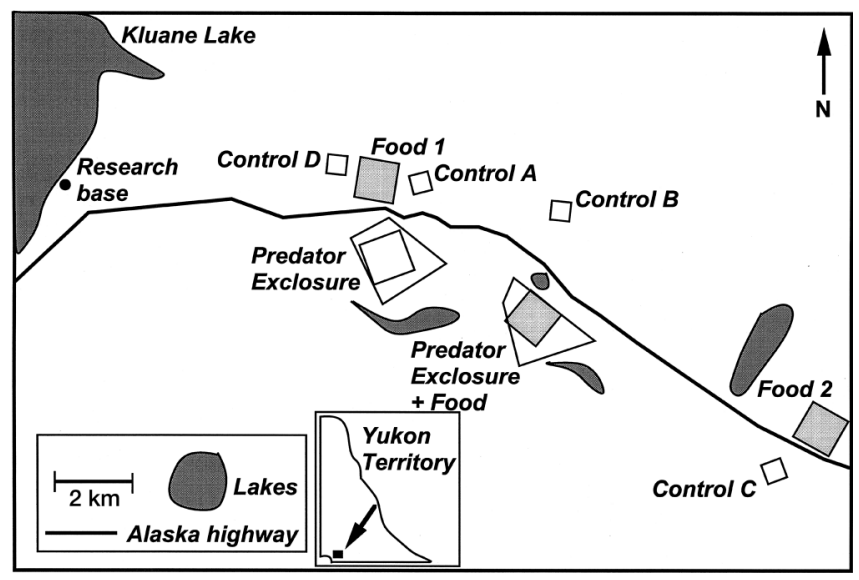

density would be highest on the predator-exclusion plus supplemental-food grid.

\section{Methods}

\section{Study sites}

Arctic ground squirrel populations were monitored in northern boreal forest in the southwestern Yukon Territory, Canada $\left(61^{\circ} \mathrm{N}\right.$, $138^{\circ} \mathrm{W}$ ) (Fig. 1). Squirrels were studied on eight 9-ha experimental grids containing 100 grid points spaced $30 \mathrm{~m}$ apart and located in a $10 \times 10$ array: $(i)$ four unmanipulated control grids (controls A, B, C, and D; controls A and B were trapped from 1990 to 1995, control C from 1993 to 1995, and control D from 1992 to 1995); (ii) two food-supplemented grids (food 1 and food 2) nested within snowshoe hare trapping grids and provisioned ad libitum with pelleted rabbit chow (minimum 16\% crude protein) distributed with a fertilizer spreader along four 600-m lines cut through the forest; (iii) one predator-exclosure grid nested within a $1-\mathrm{km}^{2}$ area surrounded by a $8600-\mathrm{V}$ electric fence to exclude large terrestrial mammalian predators and partially covered by monofilament fishing lines spaced $20 \mathrm{~cm}$ apart to deter avian predators; and (iv) one predatorexclosure + food-supplemented grid nested within a $1-\mathrm{km}^{2}$ area surrounded by an electric fence, as above, and provisioned with pelleted rabbit chow, as above, but with no monofilament lines to deter avian predators. The predator-exclosure, food, and predator-exclosure + food-supplemented grids were all located within experimental treatments established to manipulate snowshoe hare populations, as described in Boutin et al. (1995), Krebs et al. (1995), Hubbs and Boonstra (1997), and Hodges et al. (1999). Squirrels were able to move freely in and out of the experimental plots at all times.

Both the predator-exclosure and predator-exclosure + foodsupplemented treatments were exceedingly costly and difficult to maintain, particularly during the winter months (Krebs et al. 1995). Because of these practical limitations, the treatments were not replicated, a common problem with large-scale or long-term field experiments (Hurlbert 1984; Carpenter 1989). We took precautions to avoid potential misinterpretations of data resulting from these treatments; first, our control sites were replicated to enable us to examine variability in population density and survival on unmanipulated sites and, second, all our study sites were located on areas of approximately similar habitat (predominantly open spruce and shrub-meadow; Hubbs and Boonstra 1997). Although these measures do not solve the problem of a lack of replication, they do mitigate the possibility that the results presented herein are attributable merely to site-specific anomalies.

\section{Population monitoring and annual population censuses}

Population density and survival of arctic ground squirrels were measured from 1990 to 1995 (Hubbs 1994; Karels 1996; Byrom 1997). The population density of arctic ground squirrels on each of the experimental treatments and controls was estimated twice each year: once in spring (first 2 weeks of May), to estimate spring density and overwinter survival, and once in late summer (last 2 weeks of July), to estimate density after reproduction and juvenile recruitment but prior to hibernation. Adult arctic ground squirrels were trapped in Tomahawk live traps $(14 \times 14 \times 40 \mathrm{~cm}$; Tomahawk Live Trap Co., Tomahawk, Wis.) baited with peanut butter, tagged with monel No. 1005-1 tags (National Band and Tag Co., Newport, Ky.) in both ears, weighed to the nearest $5 \mathrm{~g}$ with a Pesola spring scale, and sexed. Juvenile arctic ground squirrels were trapped at emergence from the natal burrow in June, to measure reproduction on all grids. From 1990 to 1992, arctic ground squirrels were trapped at their burrows. One trap was placed at each burrow entrance, and 2-6 traps were placed at large perennial burrow systems with multiple entrances. Traps were set at 08:00, checked twice each morning at 2-h intervals, and closed at 12:00 (Hubbs and Boonstra 1997). Arctic ground squirrels were trapped for 2 consecutive days (to give a total of four trapping sessions) and population densities were estimated using program CAPTURE (Otis et al. 1978). From 1993 to 1995, arctic ground squirrels were trapped at burrows only on the food and predator-exclosure + food-supplemented grids. On the predator-exclosure and control grids, arctic ground squirrels were trapped at alternate grid stakes, with one trap at each alternate stake. From 1993 onwards, for both burrow- and stake-trapping, traps were set at 07:00, checked three times each morning at 1.5-h intervals, and closed by 12:30. Captures from the three daily trapping sessions were pooled to give an overall daily capture rate. This procedure was repeated for at least 3 consecutive days, until the population estimate had a standard error of $\leq 10 \%$. Estimates were calculated using the mark-recapture heterogeneity (jacknife) model (Pollock et al. 1990) from program CAPTURE (Otis et al. 1978), as recommended by Boulanger and Krebs (1994) and Menkens and Anderson (1988). Our confidence that these estimates reflected true demographic parameters was also supported by high JollySeber estimates of trappability ( $77 \%$ for adults and $88 \%$ for juveniles, range 22-100\%; Hubbs and Boonstra 1997) and by population estimates that had consistent bias over the number of animals captured (linear regression $N=51 ; r^{2}=0.99, p<0.0001$ ), despite a range of 3-353 animals captured among study sites. Comparisons of density estimates were made using a randomized-intervention analysis (RIA Manly 1991), to determine whether differences observed among treatments were greater than expected by chance, given the background variation in population size shown by control populations. RIA was chosen over conventional statistical tests, because of the lack of replication of the predator-exclosure and predator-exclosure + food-supplemented treatments.

From 1992, adult arctic ground squirrels were radio-collared with 5-g radio collars (PD-2C transmitters; Holohill Systems Limited, Woodlawn, Ont.), to estimate active-season survival from emergence in April to immergence in August or September (sample sizes in Table 1). Most adults were collared at emergence in the spring, with the staggered entry of a few individuals on each treatment as the season progressed. From 1992 to 1995, juvenile arctic ground squirrels were radio-collared with 6-g expandable collars (SM-1 transmitters from AVM in California and SS-2 transmitters from Biotrack, Dorset, England; both with $\mathrm{Hg}-675$ batteries), to estimate active-season survival (Byrom and Krebs 1999). We located adults twice per week and juveniles at least every 2 days, using a hand-held yagi antenna. Survival was estimated using the Kaplan- 
Table 1. The number of adult arctic ground squirrels radio-collared on treatment and control grids, and the proportion of the estimated population that was radio-collared from 1992 to 1995.

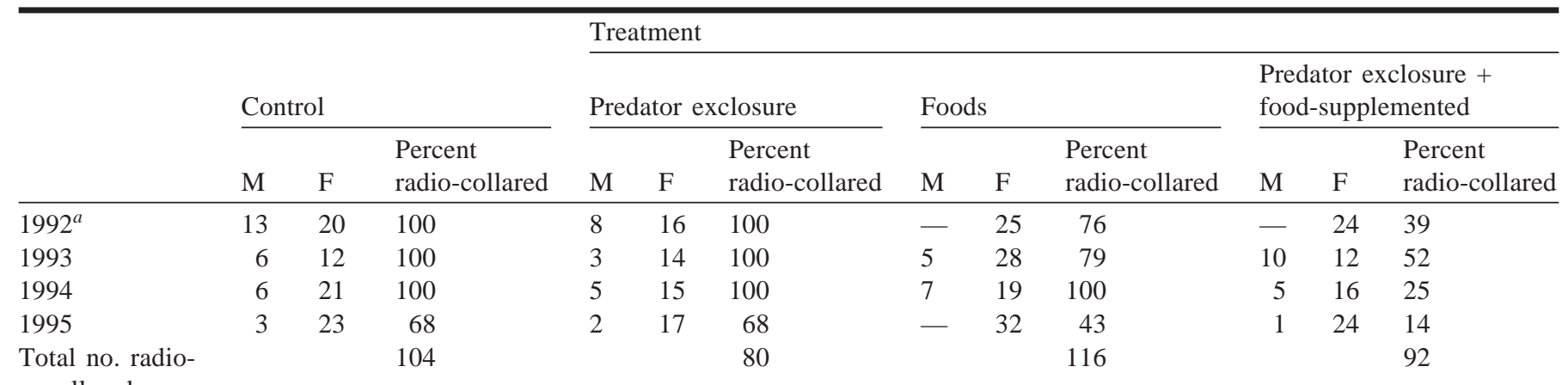
collared

Note: M, males; F, females.

${ }^{a}$ Data for 1992, from Hubbs and Boonstra (1997), used with permission.

Fig. 2. (a) Arctic ground squirrel population density (number of squirrels/ha) from 1990 to 1995 on four control grids (pooled and averaged), two food-supplemented grids, a predator-exclosure grid, and a predator-exclosure + food-supplemented grid. (b) Arctic ground squirrel population density (number of squirrels/ha) on four control grids. Controls A and B were trapped from 1990 to 1995, control C from 1993 to 1995, and control D from 1992 to 1995. Note that the scales on the $y$ axes are different in $a$ and $b$; SPR., spring; SUM., summer.

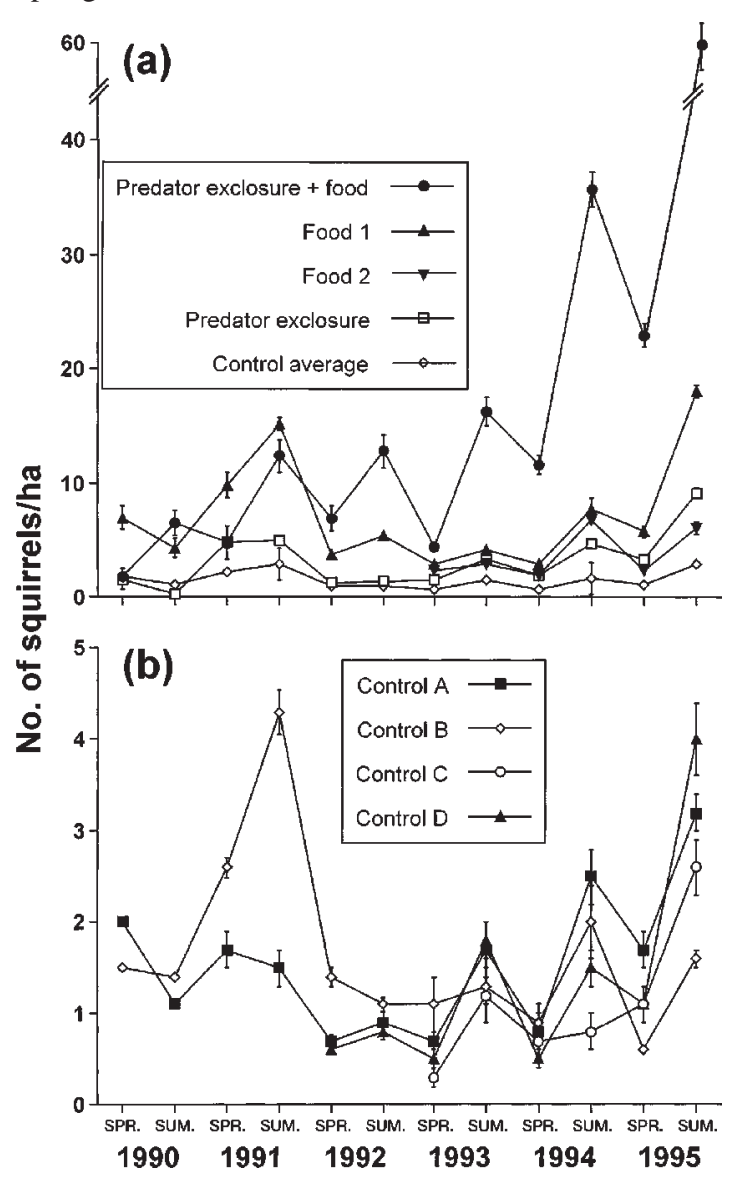

Meier estimator (Pollock et al. 1989), modified for use in MS-DOS by Krebs (1989). Survival estimates were compared using a general $\chi^{2}$ statistic (Sauer and Williams 1989; Sokal and Rohlf 1995). Overwinter survival of radio-collared arctic ground squirrels from all age and sex classes was measured in winters 1993-1994 $(n=$ 20) and 1994-1995 $(n=41)$. Squirrels were radio-collared in the fall with PD-2C transmitters (Holohill Systems Limited, Woodlawn, Ont.) and located in the spring.

\section{Population trends in arctic ground squirrels, snowshoe hares, and predators}

Instantaneous rates of population change in arctic ground squirrel populations were calculated as:

$$
r=\ln [N(t+1) / N(t)]
$$

where $N(t+1)$ is population density at time $t+1, N(t)$ is population density at time $t$, and $r$ is the instantaneous rate of population change per year (Caughley 1977). Spring population estimates were used to calculate rates of change. We then used a multiple regression to evaluate the importance of various demographic parameters (per capita reproductive output and overwinter survival, both from Karels et al. (2000), and adult and juvenile survival during the active season) on rates of population change during our study. Changes in avian- and mammalian-predator numbers (calculated in autumn of each year) and snowshoe hare autumn population densities were also monitored from 1990 to 1995 . Methods for estimating the populations of these species have been described in detail elsewhere (hares, Krebs et al. 1992; Boutin et al. 1995; lynx and coyotes, Boutin et al. 1995; O'Donoghue et al. 1997; avian predators, Doyle and Smith 1994).

\section{Results}

Population density and rates of population change

We tested whether the change in trapping method (from burrow-trapping to stake-trapping on the predator-exclosure and control grids) affected population estimates, by trapping squirrels on the predator-exclosure grid using both methods in spring 1993. Burrow-trapping gave a population estimate of $12 \pm 0$ squirrels (95\% confidence limits; total number captured $=12$ ), whereas the same population trapped at stakes within a few days gave a population estimate of $13 \pm 0$ squirrels (total number captured $=13$ ), so we assumed that estimates of population density made using the two methods were comparable.

Population densities of arctic ground squirrels on control and experimental grids declined after a peak in 1990 and 1991 (Fig. 2), during and immediately after the peak in snowshoe hare numbers. Densities were low on all sites by the spring of 1993 and increased thereafter. Treatments had 
Fig. 3. Ratio of population densities of arctic ground squirrels on each experimental treatment (predator exclosure, food 1 and food 2 , and predator exclosure + food-supplemented) to population densities on controls A-D (pooled and averaged) from 1990 to 1995. Arrows show the average increase in population density on each experimental treatment relative to the average control density over all years. Note that the scales on the $y$ axes are different; SPR., spring; SUM., summer.

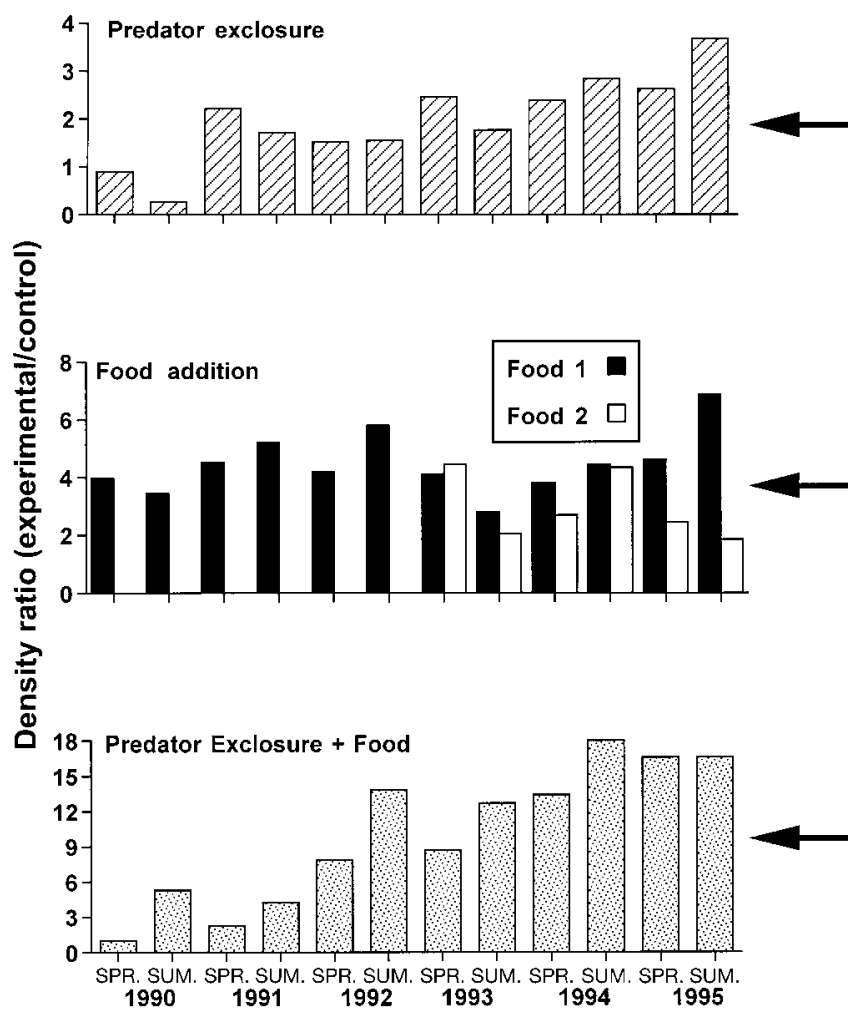

considerably higher population densities than controls in most years, with variability among controls being similar throughout the study. RIA revealed significant differences in densities for the predator-exclosure + food-supplemented (5000 of 5000 randomizations < observed, $p<0.001$ ) and food (4967 of 5000 randomizations < observed, $p<0.01$ ) treatments but revealed no significant increase in density for the predator-exclosure treatment (3171 of 5000 randomizations < observed, $p=0.37$ ). On average, with predator exclusion alone, arctic ground squirrel population densities increased twofold, while with food addition alone, densities increased fourfold. Population densities increased 10-fold, on average, when food was added and predators were removed simultaneously (Fig. 3).

On all grids, instantaneous rates of population change, $r$, were positive from 1990 to 1991, negative from 1991 to 1993 (with one exception), and positive from 1993 to 1995 (with one exception) (Fig. 4). In contrast with all other treatments and controls, the predator-exclosure + food-supplemented treatment sustained a positive rate of population growth from 1991 to 1992 , and the population declined for only 1 year (1992-1993) before increasing again from 1993 to 1995 (Fig. 4). The strongest predictor of $r$ from year to year was active-season survival of adults (see below) $\left(r^{2}=0.45, n=\right.$ $12 ; F=4.9, p<0.06)$. Overwinter survival and per capita reproductive output had negligible influence on the rate of
Fig. 4. Instantaneous rates of population change per year on four control grids, two food-supplemented grids, a predator-exclosure grid, and a predator-exclosure + food-supplemented grid from spring 1990 to spring 1995. Note that the instantaneous rate of population change per year, $r$, was zero on the predator exclosure in 1992-1993.

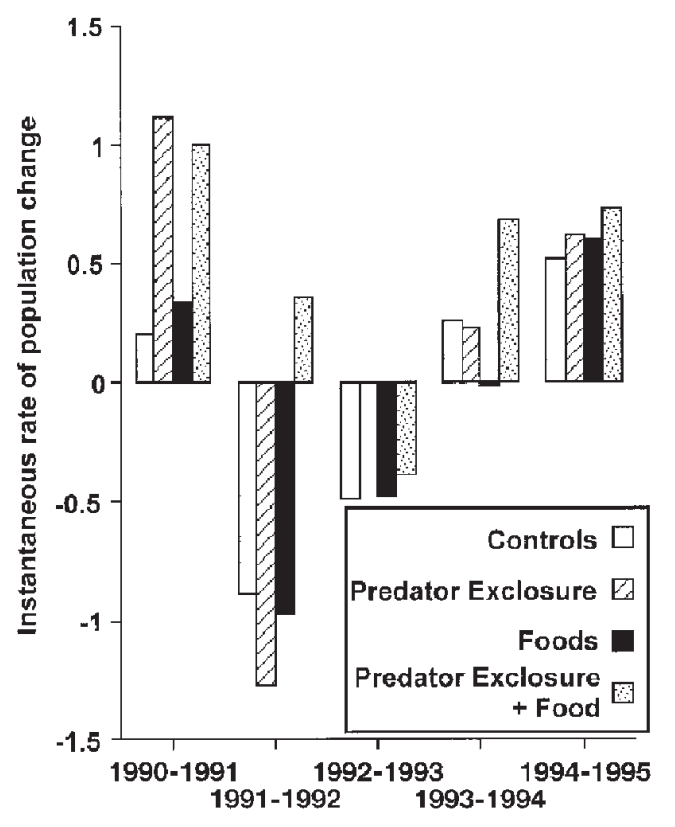

population change in arctic ground squirrel populations at Kluane.

\section{Active-season survival}

Because the adult sex ratio was biased in favour of females, sample sizes of radio-collared adult males were often too small to allow comparisons of survival to be made within each sex on all treatments, so we present results for survival analyses of the two sexes combined. Predation was the greatest proximate cause of mortality during the active season for radio-collared ground squirrels in all years. Predation accounted for 42 of 45 known adult mortalities in 1992 (Hubbs and Boonstra 1997), 18 of 18 mortalities in 1993, seven of seven mortalities in 1994, and six of six mortalities in 1995. Predation accounted for six of six juvenile mortalities in 1992, 21 of 21 mortalities in 1993, 16 of 18 mortalities in 1994, and 15 of 15 mortalities in 1995. In total, predation accounted for 96\% (125/130) of all known deaths of adult and juvenile arctic ground squirrels during this study. Most kills (75\% of known adult kills and $79 \%$ of known juvenile kills) were by avian predators. From 1993 to 1995, the predator-exclosure + food-supplemented treatment had a strong significant effect on adult survival, and the effects of the treatments on adult survival were ranked as follows: predator exclosure + food-supplemented $>$ food $>$ predator exclosure $>$ controls (Table 2). We excluded the results for 1992 from our analyses of treatment effects on adult survival, because during 1993-1995, population growth in the arctic ground squirrel population was positive (Fig. 4) and numbers of predators were lower, whereas during 1992 predation was high. Twenty-eight day survival was significantly lower in 1992 than from 1993 to 1995 for radio-collared adults (Table 2), as it was for radio-collared juveniles 
Table 2. Results of statistical analyses comparing 28-day activeseason survival of radio-collared adult arctic ground squirrels among experimental treatments and controls from 1992 to 1995 , and comparing pooled survival on all treatments among years.

\begin{tabular}{|c|c|c|c|c|}
\hline Year and treatment & $\begin{array}{l}\text { Survival } \\
(\text { mean } \pm \mathrm{SE})\end{array}$ & $N$ & $\chi^{2}$ & $p$ \\
\hline \multicolumn{5}{|l|}{1992} \\
\hline Controls & $0.788 \pm 0.02$ & 33 & \multirow{4}{*}{30.3} & \multirow{4}{*}{$<0.0001$} \\
\hline Predator exclosure & $0.813 \pm 0.027$ & 24 & & \\
\hline Foods & $0.704 \pm 0.02$ & 25 & & \\
\hline $\begin{array}{l}\text { Predator exclosure }+ \\
\text { food-supplemented }\end{array}$ & $0.658 \pm 0.027$ & 24 & & \\
\hline \multicolumn{5}{|l|}{1993} \\
\hline Controls & $0.705 \pm 0.107$ & 18 & \multirow{4}{*}{13.0} & \multirow{4}{*}{0.005} \\
\hline Predator exclosure & $0.886 \pm 0.041$ & 17 & & \\
\hline Foods & $0.882 \pm 0.041$ & 33 & & \\
\hline $\begin{array}{l}\text { Predator exclosure }+ \\
\quad \text { food-supplemented }\end{array}$ & $0.974 \pm 0.015$ & 22 & & \\
\hline \multicolumn{5}{|l|}{1994} \\
\hline Controls & $0.968 \pm 0.015$ & 27 & \multirow{4}{*}{6.8} & \multirow{4}{*}{0.08} \\
\hline Predator exclosure & $0.949 \pm 0.026$ & 20 & & \\
\hline Foods & $1.000 \pm 0$ & 26 & & \\
\hline $\begin{array}{l}\text { Predator exclosure }+ \\
\text { food-supplemented }\end{array}$ & $1.000 \pm 0$ & 21 & & \\
\hline \multicolumn{5}{|l|}{1995} \\
\hline Controls & $0.884 \pm 0.051$ & 26 & \multirow{4}{*}{10.1} & \multirow{4}{*}{0.017} \\
\hline Predator exclosure & $0.970 \pm 0.015$ & 19 & & \\
\hline Foods & $1.000 \pm 0$ & 32 & & \\
\hline $\begin{array}{l}\text { Predator exclosure }+ \\
\text { food-supplemented }\end{array}$ & $1.000 \pm 0$ & 25 & & \\
\hline \multicolumn{5}{|l|}{ Treatments pooled } \\
\hline 1992 & $0.741 \pm 0.025$ & 106 & \multirow{4}{*}{91.7} & \multirow{4}{*}{$<0.0001$} \\
\hline 1993 & $0.868 \pm 0.026$ & 90 & & \\
\hline 1994 & $0.980 \pm 0.01$ & 94 & & \\
\hline 1995 & $0.967 \pm 0.01$ & 102 & & \\
\hline \multicolumn{5}{|l|}{ 1993-1995 pooled } \\
\hline Controls & $0.863 \pm 0.019$ & 104 & \multirow{4}{*}{59.0} & \multirow{4}{*}{$<0.0001$} \\
\hline Predator exclosure & $0.940 \pm 0.015$ & 80 & & \\
\hline Foods & $0.959 \pm 0.011$ & 116 & & \\
\hline $\begin{array}{l}\text { Predator exclosure }+ \\
\text { food-supplemented }\end{array}$ & $0.993 \pm 0.004$ & 92 & & \\
\hline
\end{tabular}

Note: For all comparisons, $\mathrm{df}=3$.

(Table 3). However, our experimental manipulations did not have a consistent effect on juvenile survival (Table 3 ). Treatment effects on juvenile survival, although not significant, were ranked as follows: food > controls > predator exclosure > predator exclosure + food-supplemented (Table 3). However, juvenile survival varied significantly among years, with the lowest survival in 1992.

We also calculated survival of both adult and juvenile arctic ground squirrels on the predator-exclosure grid, selecting only those that stayed within the fence and under the protection of the monofilament fishing line. Survival of both adult and juvenile squirrels that remained under the monofilament fishing line during the active season was significantly higher than the overall survival on the predator-exclosure grid $\left(\chi^{2}=\right.$ 31.7, df $=1, p<0.0001$; Table 4).

In the summer of 1993 (a year of moderately high predation for arctic ground squirrels), we tested the assumption
Table 3. Results of statistical analyses comparing 28-day activeseason survival of radio-collared juvenile arctic ground squirrels among experimental treatments and controls (only on control A in 1992 and on controls A and D from 1993 to 1995), and comparing pooled survival on all treatments among years.

\begin{tabular}{|c|c|c|c|c|}
\hline Year and treatment & $\begin{array}{l}\text { Survival } \\
(\text { mean } \pm \mathrm{SE})\end{array}$ & $N$ & $\chi^{2}$ & $p$ \\
\hline \multicolumn{5}{|l|}{1992} \\
\hline Control & $0.476 \pm 0.168$ & 12 & - & - \\
\hline \multicolumn{5}{|l|}{1993} \\
\hline Controls & $0.908 \pm 0.046$ & 8 & & \\
\hline Predator exclosure & $0.680 \pm 0.077$ & 17 & & \\
\hline Foods & $0.812 \pm 0.066$ & 15 & 8.8 & 0.03 \\
\hline $\begin{array}{r}\text { Predator exclosure }+ \\
\text { food-supplemented }\end{array}$ & $0.916 \pm 0.041$ & 11 & & \\
\hline \multicolumn{5}{|l|}{1994} \\
\hline Controls & $0.744 \pm 0.087$ & 12 & & \\
\hline Predator exclosure & $0.802 \pm 0.066$ & 15 & & \\
\hline Foods & $0.934 \pm 0.036$ & 18 & 10.2 & 0.017 \\
\hline $\begin{array}{l}\text { Predator exclosure }+ \\
\text { food-supplemented }\end{array}$ & $0.958 \pm 0.02$ & 15 & & \\
\hline \multicolumn{5}{|l|}{1995} \\
\hline Controls & $0.810 \pm 0.082$ & 16 & & \\
\hline Predator exclosure & $0.967 \pm 0.015$ & 14 & & \\
\hline Foods & $0.868 \pm 0.056$ & 16 & 18.6 & 0.0003 \\
\hline $\begin{array}{l}\text { Predator exclosure }+ \\
\text { food-supplemented }\end{array}$ & $0.523 \pm 0.122$ & 15 & & \\
\hline \multicolumn{5}{|l|}{ Treatments pooled } \\
\hline 1992 & $0.476 \pm 0.168$ & 12 & & \\
\hline 1993 & $0.811 \pm 0.031$ & 51 & & \\
\hline 1994 & $0.862 \pm 0.02$ & 60 & 9.9 & 0.02 \\
\hline 1995 & $0.765 \pm 0.041$ & 61 & & \\
\hline \multicolumn{5}{|l|}{ 1993-1995 pooled } \\
\hline Controls & $0.815 \pm 0.038$ & 48 & & \\
\hline Predator exclosure & $0.796 \pm 0.036$ & 46 & & \\
\hline Foods & $0.872 \pm 0.031$ & 49 & 3.9 & 0.28 \\
\hline $\begin{array}{l}\text { Predator exclosure }+ \\
\text { food-supplemented }\end{array}$ & $0.773 \pm 0.056$ & 41 & & \\
\hline
\end{tabular}

Note: For all comparisons, $\mathrm{df}=3$.

Table 4. Twenty-eight day active-season survival of radiocollared arctic ground squirrels on the predator-exclosure treatment from 1993 to 1995 .

\begin{tabular}{|c|c|c|c|c|}
\hline & \multicolumn{2}{|c|}{ Overall survival } & \multicolumn{2}{|c|}{ Protected survival } \\
\hline & Mean $\pm \mathrm{SE}$ & $N$ & Mean $\pm \mathrm{SE}$ & $N$ \\
\hline \multicolumn{5}{|l|}{1993} \\
\hline Adults & $0.886 \pm 0.041$ & 17 & $0.929 \pm 0.036$ & 9 \\
\hline Juveniles & $0.680 \pm 0.077$ & 17 & $1.000 \pm 0$ & 8 \\
\hline \multicolumn{5}{|l|}{1994} \\
\hline Adults & $0.949 \pm 0.026$ & 20 & $1.000 \pm 0$ & 9 \\
\hline Juveniles & $0.802 \pm 0.066$ & 15 & $1.000 \pm 0$ & 9 \\
\hline \multicolumn{5}{|l|}{1995} \\
\hline Adults & $0.970 \pm 0.015$ & 19 & $1.000 \pm 0$ & 13 \\
\hline Juveniles & $0.967 \pm 0.015$ & 14 & $1.000 \pm 0$ & 11 \\
\hline
\end{tabular}

Note: "Overall survival" means survival of all arctic ground squirrels moving freely in and out of the treatment area. "Protected survival" means survival of only those arctic ground squirrels that remained under the monofilament fishing line within the grid. 
Table 5. The number of radio-collared arctic ground squirrels surviving overwinter on treatment and control grids in winters 1993-1994 and 1994-1995.

\begin{tabular}{|c|c|c|c|c|}
\hline & Controls & $\begin{array}{l}\text { Predator } \\
\text { exclosure }\end{array}$ & Foods & $\begin{array}{l}\text { Predator exclosure }+ \\
\text { food-supplemented }\end{array}$ \\
\hline \multicolumn{5}{|l|}{ Adults } \\
\hline \multicolumn{5}{|l|}{ Females } \\
\hline 1993-1994 & $4(4)$ & - & $1(1)$ & - \\
\hline 1994-1995 & $1(1)$ & - & $7(8)$ & $7(7)$ \\
\hline \multicolumn{5}{|l|}{ Males } \\
\hline 1993-1994 & - & - & $3(4)$ & - \\
\hline 1994-1995 & $1(1)$ & $4(4)$ & $0(1)$ & - \\
\hline \multicolumn{5}{|l|}{ Juveniles } \\
\hline \multicolumn{5}{|l|}{ Females } \\
\hline 1993-1994 & $3(3)$ & $4(4)$ & $1(2)$ & - \\
\hline 1994-1995 & $4(4)$ & $5(6)$ & $1(1)$ & $5(6)$ \\
\hline \multicolumn{5}{|l|}{ Males } \\
\hline 1993-1994 & - & $1(2)$ & - & - \\
\hline 1994-1995 & - & - & $1(1)$ & $1(1)$ \\
\hline
\end{tabular}

Note: Values in parentheses are sample size.

that squirrel mortalities occurred as a result of predation and not from scavenging by placing 12 whole dead squirrels (obtained from road kills) randomly on three control sites and leaving them for several days. The fate of each squirrel was monitored using the spool and line technique (Boonstra and Craine 1986). Ten of the 12 squirrels were dragged 30-80 m to red squirrel middens, one was dragged to a ground squirrel burrow, and one remained untouched. None of the 12 squirrels showed any of the diagnostic signs we normally used to determine that predation had occurred on radio-collared squirrels (plucked fur, feathers, whitewash, or pellets in the case of avian predation; piles of intestines or scats in the case of mammalian predation), so we assumed that observed mortalities of radio-collared squirrels were the result of predation events and not of scavenging.

\section{Overwinter survival}

Overwinter survival of 61 radio-collared squirrels was high in the winters 1993-1994 and 1994-1995, the only seasons in which arctic ground squirrels were radio-collared over winter (Table 5). There appeared to be no differences in survival of squirrels among treatments or years. However, statistical analyses were not appropriate, given the small sample sizes within each age and sex class. Hubbs and Boonstra (1997) also found that overwinter survival of (uncollared) arctic ground squirrels in the boreal forest did not differ with age, year, or treatment, although females had a slight survival advantage in one of the two seasons in which they monitored overwinter survival. In addition, survival of squirrels in all age and sex classes was lowest in the winter 1991-1992 (Hubbs and Boonstra 1997).

\section{Population trends in arctic ground squirrels, snowshoe hares, and predators}

Snowshoe hare numbers declined from 1989 to 1993 and remained low until 1995. The numbers of mammalian and avian predators peaked in 1990 and 1992, respectively. Arctic ground squirrel densities peaked in 1991 and were lowest in 1993. Survival of adults declined from 1990 to 1993 and survival of juveniles was lowest in 1992 (Fig. 5). Arctic ground squirrel population densities and survival showed lagged fluctuations that may have occurred in response to the snowshoe hare cycle and the resultant increase and decline in predator numbers.

\section{Discussion}

Our experimental findings support the hypothesis that predators and food availability may interact to limit arctic ground squirrel populations at Kluane during the decline and low phases of a snowshoe hare cycle. On average, exclusion of predators resulted in a twofold increase in arctic ground squirrel population densities, food-supplementation resulted in a fourfold increase, and predator removal and food addition together resulted in a 10-fold increase. Had this effect been simply additive, we would have expected an approximately sixfold increase in density on the predator-exclosure + food-supplemented treatment. Survival was also significantly higher on the experimental sites than on the control sites during the decline and low phases of a snowshoe hare cycle. Changes in adult survival also contributed to interyear variation in arctic ground squirrel populations in the boreal forest, resulting in a strong effect on rates of population change, and thus providing a mechanism whereby squirrel populations could increase dramatically when predators declined after 1993.

Large-scale experimental manipulations are often costly to maintain and difficult to replicate (Carpenter et al. 1995; Krebs et al. 1995). Hence, the predator-exclosure and the predator-exclosure + food-supplemented treatments were not replicated in this study. Drawing conclusions from ecological studies without replication can be problematic (Hurlbert 1984; Carpenter 1989). However, we believe that the observed changes in population density on the experimental treatments were real for the following reasons. First, although the predatorexclosure + food-supplemented and the predator-exclosure treatments were not replicated, the control sites were. Similar trends in population density were observed among the four controls during our study (Fig. 2b). Second, all our grids were located in areas of similar habitat (predominantly 
Fig. 5. Population densities of arctic ground squirrels, predators, and snowshoe hares in the southwestern Yukon Territory from 1989 to 1995 . Note that the scales on the $y$ axes are different. (a) Autumn population densities of snowshoe hares (number of hares/ha) on control grids from 1989 to 1995. (b) Latesummer population densities of arctic ground squirrels (number of squirrels/ha) on control grids from 1990 to 1995. (c) Autumn population densities of mammalian predators (number of lynx and coyotes $/ 350 \mathrm{~km}^{2}$ ) from 1989 to 1995 . (d) Summer population densities of avian predators (number of pairs of great horned owls, red-tailed hawks, and goshawks $/ 100 \mathrm{~km}^{2}$ ) from 1989 to 1995 . (e) Twenty-eight day active-season survival of adult (A) and juvenile (J) arctic ground squirrels on control sites from 1990 to 1995. Active-season survival was estimated from trapping data for 1990 and 1991 (Hubbs and Boonstra 1997) and by radiotelemetry for 1992-1995 (Byrom 1997).
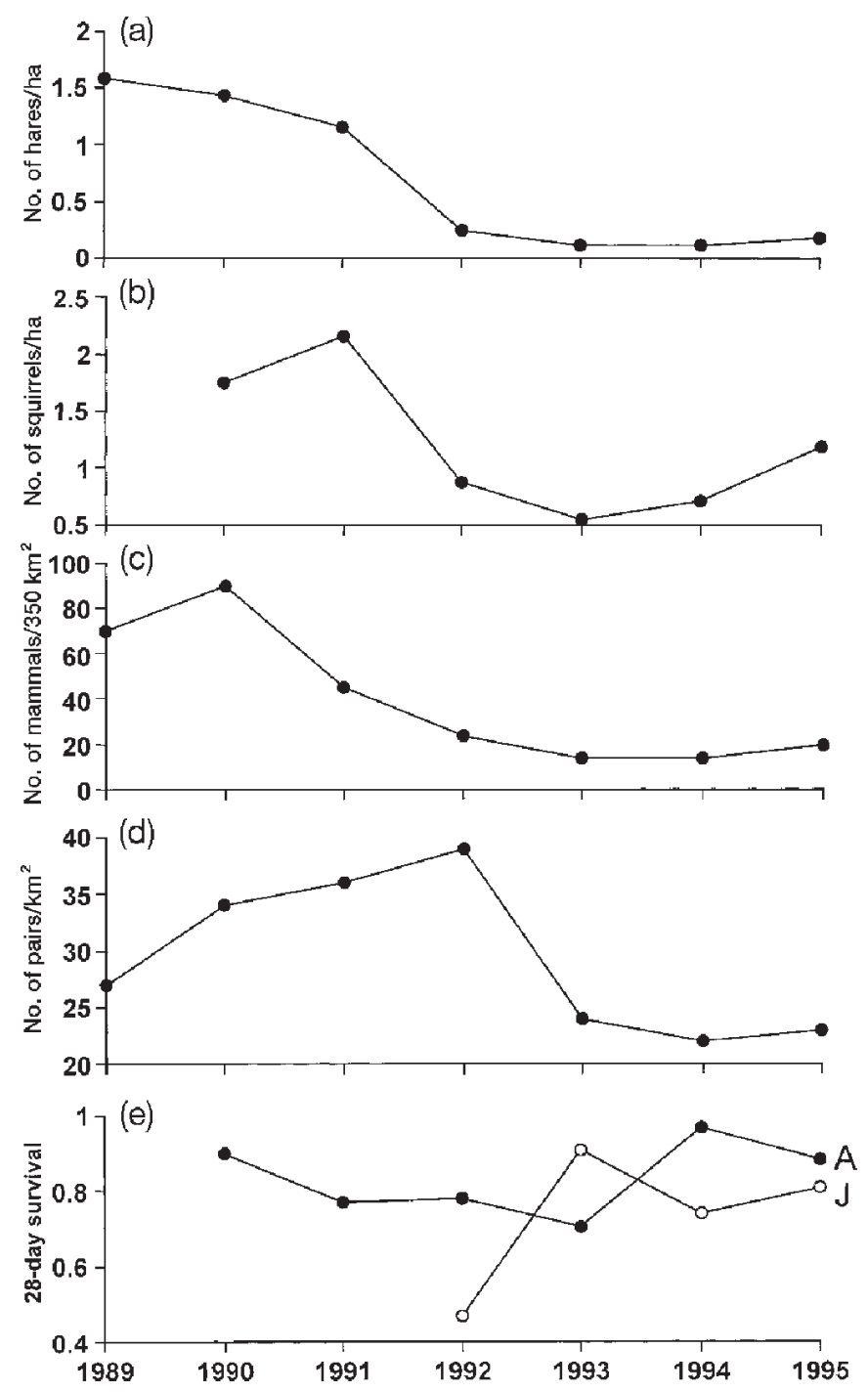

open spruce and shrub-meadow; Hubbs and Boonstra 1997). Hence, observed demographic changes are unlikely to be habitat-specific anomalies.

We are confident that results obtained from burrow-trapping and trapping at stakes on all grids are directly comparable. First, similar population estimates were obtained on the predator-exclosure grid in 1993 using the two methods. Sec- ond, the minimum distance between any two traps (i.e., the diagonal distance between alternate traps) was $44 \mathrm{~m}$, whereas home-range diameters (estimated using the 95\% minimum convex polygon method; Jennrich and Turner 1969) for arctic ground squirrels on control and predator-exclosure grids ranged from 145 to $174 \mathrm{~m}$ (Byrom and Krebs 1999). We therefore assumed that there was a high probability of a squirrel encountering a trap during normal daily movement. Third, the dispersion of trap-capture rates among squirrels approximated a Poisson distribution on each grid in each trapping session, indicating that a high proportion of empty traps were always available to capture squirrels. Finally, we compared our density estimates with the minimum number of squirrels known to be alive (MNA) for each treatment at each trapping session. The MNA:density ratio varied from 0.7 to 1.2 for all grids in all trapping sessions, and these ratios did not change consistently among grids, among years, or with increasing density, so we were confident that the burrow-trapping method was accurate for all sites.

In all years except 1992, adult survival was significantly increased on all three treatments relative to controls (Table 2), in spite of the fact that arctic ground squirrels were able to move freely in and out of the study sites. Occasionally such movements did result in a predation event, particularly for juveniles (Byrom and Krebs 1999) but also for adults. On the predator exclosure, for example, the survival of both adults and juveniles that remained under the monofilament fishing line was significantly higher than the overall survival of squirrels from that treatment (Table 4). Two further lines of evidence support the argument that survival differences contributed to the observed population changes; first, three adult squirrels were killed by avian predators inside the predator exclosures in 1993 and, second, the majority of known squirrel kills were by raptors. If all avian kills inside the fences and under the monofilament fishing line could have been prevented, and if the exclosure fences had been impermeable to arctic ground squirrels, there may have been an even more pronounced effect of predator removal on squirrel survival and, likely, flow-on effects of survival on population density, as well. Therefore, these results could be regarded as conservative, because they underestimate the potential effects of avian predation on arctic ground squirrel populations and its likely interaction with food availability.

We did not attempt to prevent arctic ground squirrels from moving freely in and out of our study sites for two reasons. First, our experimental grids were $300 \times 300 \mathrm{~m}$ in size but were located within larger $\left(1 \mathrm{~km}^{2}\right)$ fenced or foodsupplemented areas, so we were able to maintain a large buffer population of squirrels around all our manipulated areas. Second, we wanted to avoid the "fence effect," a phenomenon common among microtine rodents, whereby fenced populations show high rates of population increase, resulting in a sharp decline in food availability and a sudden population crash (Krebs et al. 1969). The fence effect commonly occurs when dispersers are prevented from leaving an area and, although it has not been demonstrated for populations of ground-dwelling sciurids, we believe that there was potential for it to occur. Results obtained by monitoring a squirrel population that was able to move freely in and out of the study areas outweighed the costs of losing some squirrels to predation as a consequence. 
Changes in survival of both adults and juveniles during the study period also influenced interyear variation in arctic ground squirrel populations from 1990 to 1995; this is demonstrated by the significant effect of survival on the rate of population change, and the decline in active-season survival and the negative population growth rates from 1991 to 1993 , when predation intensity was probably highest as a result of the snowshoe hare cyclic decline (Fig. 5). Active-season survival of adults and juveniles was lowest in 1992 (and to some extent in 1993), when predators were using arctic ground squirrels as alternative prey during the summer (Rohner 1994; O'Donoghue et al. 1998). In addition, adult survival was consistently high in 1994 and 1995, when predator numbers (and probably predation intensity) were low. To a lesser extent, juvenile survival also followed this trend. During our study, overwinter losses of radio-collared squirrels were minimal (Karels 1996; Byrom 1997; Table 5), although Hubbs and Boonstra (1997) suggested that high losses caused by severe weather conditions in early spring 1992 may have contributed to the decline in arctic ground squirrel populations immediately following the snowshoe hare decline from 1991 to 1992.

Impacts of predators on density and survival of alternative prey species as a result of a cyclic decline in another herbivore are often reported (e.g., Angelstam et al. 1984; Sutherland 1988; Marcström et al. 1989; Keith and Cary 1991; Korpimäki and Norrdahl 1991; Small and Keith 1992; Patterson et al. 1998; Angerbjorn et al. 1999). Keith and Cary (1991) inferred that increased predation may have occurred on populations of alternative prey (including Franklin's ground squirrels, Spermophilus franklinii) during a snowshoe hare population decline in Alberta. Steenhof and Kochert (1988) reported that Townsend's ground squirrels (Spermophilus townsendii) were alternative prey for golden eagles (Aquila chrysaetos) during a jackrabbit (Lepus californicus) decline in Idaho. Marcström et al. (1989) concluded that arctic hare (Lepus timidus) population densities and growth rates declined in response to increased predation by red foxes (Vulpes vulpes) and martens (Martes martes), when populations of Microtus spp. and Clethrionomys spp. declined on two islands in the northern Baltic Sea. Sutherland (1988) summarized evidence indicating that changes in survival rates of Brant geese may be due to predators such as arctic foxes (Alopex lagopus) switching to goose eggs and goslings as a consequence of the cyclic decline of lemmings on the Taimyr peninsula in Siberia. Arctic ground squirrel population densities at Kluane were likely also indirectly influenced by snowshoe hare population densities as a result of hare predators, particularly raptors, concentrating foraging efforts on squirrels after hare populations declined (Rohner 1994; O'Donoghue et al. 1998). The fluctuation in arctic ground squirrel populations resulting from the snowshoe hare cycle is in marked contrast with red squirrel (StuartSmith and Boutin 1995) and small-herbivore (Boutin et al. 1995) populations at Kluane, which did not fluctuate in synchrony with the snowshoe hare population at any stage of its cycle.

In this study, arctic ground squirrel populations in the southwestern Yukon demonstrated fluctuations in density and survival as a consequence of the snowshoe hare cyclic decline, which suggests that the snowshoe hare cycle indirectly affects arctic ground squirrel populations. Squirrels also responded to experimental manipulation of two external limiting factors. Although overwinter losses were negligible during our study, they may occasionally be severe (Hubbs and Boonstra 1997), introducing a stochastic element into the regular fluctuation. Hence, arctic ground squirrel populations can sustain a positive rate of increase during the low phase of the snowshoe hare cycle, particularly if activeseason survival of adults and overwinter survival are high. Elsewhere we have examined the effects of our experimental manipulations on reproduction and growth rates in arctic ground squirrels (Karels et al. 2000) and on juvenile survival and dispersal patterns (Byrom and Krebs 1999). Publications examining whether predation and food supply have densitydependent (and thus regulatory) effects on arctic ground squirrels in the boreal forest at Kluane are in preparation.

\section{Acknowledgements}

This research would not have been possible without the able and dedicated field assistance of A. Kliskey, R. Arkinstall, L. Aus, F. Danks, G. Goggin-Michaud, A. Hubbs, C. Hutchison, S. Olsen, S. Pelech, and R. Serrouya. Financial support for the Kluane project was provided to C.J. Krebs et al. through a Collaborative Special Project grant from the Natural Sciences and Engineering Research Council of Canada. A.E.B. was supported financially by a Canadian Commonwealth Scholarship. W. Lidicker, G. Michener, J. Murie, J. Myers, A.R.E. Sinclair, J.N.M. Smith, and two anonymous reviewers provided helpful comments on early versions of the manuscript. Research was conducted under permit from the Wildlife Branch of the Yukon Territorial Government. This is publication No. 127 of the Kluane Boreal Forest Ecosystem Project.

\section{References}

Abrams, P. 1994. Should prey overestimate the risk of predation? Am. Nat. 144: 317-328.

Abrams, P. 1999. Is predator-mediated coexistence possible in unstable systems? Ecology, 80: 608-621.

Andrewartha, H.G., and Birch, L.C. 1954. The distribution and abundance of animals. University of Chicago Press, Chicago.

Angelstam, P., Lindström, E., and Widén, P. 1984. Role of predation in short-term fluctuations of some birds and mammals in Fennoscandia. Oecologia, 62: 199-208.

Angerbjorn, A., Tannerfeldt, M., and Erlinge, S. 1999. Predatorprey relationships: arctic foxes and lemmings. J. Anim. Ecol. 68: $34-49$.

Banfield, A.W.F. 1974. The mammals of Canada. University of Toronto Press, Toronto.

Boonstra, R., and Craine, I.T.M. 1986. Natal nest location and small mammal tracking with a spool and line technique. Can. J. Zool. 64: 1034-1036.

Boulanger, J., and Krebs, C.J. 1994. Comparison of capturerecapture estimators of snowshoe hare populations. Can. J. Zool. 72: 1800-1807.

Boutin, S. 1990. Food supplementation experiments with terrestrial vertebrates: patterns, problems, and the future. Can. J. Zool. 68: 203-220. 
Boutin, S., Krebs, C.J., Sinclair, A.R.E., and Smith, J.N.M. 1986. Proximate causes of losses in a snowshoe hare population. Can. J. Zool. 64: 606-610.

Boutin, S., Krebs, C.J., Boonstra, R., Dale, M.R.T., Hannon, S.J., Martin, K., Sinclair, A.R.E., Smith, J.N.M., Turkington, R., Blower, M., Byrom, A., Doyle, F.I., Doyle, C., Hik, D., Hofer, L., Hubbs, A., Karels, T., Murray, D.L., Nams, V., O'Donoghue, M., Rohner, C., and Schweiger, S. 1995. Population changes of the vertebrate community during a snowshoe hare cycle in Canada's boreal forest. Oikos, 74: 69-80.

Byrom, A.E. 1997. Population ecology of arctic ground squirrels in the boreal forest during the decline and low phases of a snowshoe hare cycle. Ph.D. thesis, The University of British Columbia, Vancouver.

Byrom, A.E., and Krebs, C.J. 1999. Natal dispersal of juvenile arctic ground squirrels in the boreal forest. Can. J. Zool. 77: 10481059.

Carl, E.A. 1971. Population control in arctic ground squirrels. Ecology, 52: 395-413.

Carpenter, S.R 1989. Replication and treatment strength in wholelake experiments. Ecology, 70: 453-463.

Carpenter, S.R., Chisholm, S.W., Krebs, C.J., Schindler, D.W., and Wright, R.F. 1995. Ecosystem experiments. Science (Washington, D.C.), 269: 324-327.

Caughley, G. 1977. Analysis of vertebrate populations. John Wiley \& Sons, London.

Crawley, M.J. 1992. Overview. In Natural enemies: the population biology of predators, parasites, and diseases. Edited by M.J. Crawley. Blackwell Scientific Publications, Oxford. pp. 476489.

Desy, E.A., and Batzli, G.O. 1989. Effects of food availability and predation on prairie vole demography: a field experiment. Ecology, 70: 411-421.

Desy, E.A., Batzli, G.O., and Liu, J. 1990. Effects of food and predation on behaviour of prairie voles: a field experiment. Oikos, 58: $159-168$.

Dickman, C.R. 1992. Predation and habitat shifts in the house mouse, Mus domesticus. Ecology, 73: 313-322.

Dobson, F.S. 1995. Regulation of population size: evidence from Columbian ground squirrels. Oecologia, 102: 44-51.

Dobson, F.S., and Kjelgaard, J.D. 1985a. The influence of food resources on population dynamics in Columbian ground squirrels. Can. J. Zool. 63: 2095-2104.

Dobson, F.S., and Kjelgaard, J.D. 1985b. The influence of food resources on life history in Columbian ground squirrels. Can. J. Zool. 63: 2105-2109.

Doyle, F.I., and Smith, J.N.M. 1994. Population responses of Northern goshawks to the 10-year cycle in numbers of snowshoe hares. Stud. Avian Biol. 16: 122-129.

Elliott, C.L., and Guetig, R. 1990. Summer food habits of coyotes in Idaho's River of No Return Wilderness Area. Great Basin Nat. 50: 63-65.

Elton, C. 1927. Animal ecology. Sidgwick and Jackson, London.

Elton, C., and Nicholson, M. 1942. The ten year cycle in numbers of the lynx in Canada. J. Anim. Ecol. 11: 215-244.

Erlien, D.A., and Tester, J.R. 1984. Population ecology of sciurids in northwestern Minnesota. Can. Field-Nat. 98: 1-6.

Erlinge, S., Goransson, G., Hogstedt, G., Jansson, G., Liberg, O., Loman, J., Nilsson, I.N., von Schantz, T., and Sylven, M. 1984. Can vertebrate predators regulate their prey? Am. Nat. 23: 125133.

Errington, P.L. 1967. Of predation and life. Iowa State University Press, Ames.
Gilbert, B.S., and Krebs, C.J. 1981. Effects of extra food on Peromyscus and Clethrionomys populations of the southern Yukon. Oecologia, 51: 326-331.

Green, J.E. 1977. Population regulation and annual cycles in the arctic ground squirrel. M.Sc. thesis, The University of British Columbia, Vancouver.

Hik, D.S. 1995. Does risk of predation influence population dynamics? Evidence from the cyclic decline of snowshoe hares. Wildl. Res. 22: 115-129.

Hodges, K.E., Krebs, C.J., and Sinclair, A.R.E. 1999. Snowshoe hare demography during a cyclic population low. J. Anim. Ecol. 68: $581-594$.

Hubbs, A.H. 1994. The effects of food and predation on population regulation of the arctic ground squirrel (Spermophilus parryii plesius) during the peak and decline phases of a snowshoe hare cycle. M.Sc. thesis, University of Toronto, Toronto, Ont.

Hubbs, A.H., and Boonstra, R. 1997. Population limitation in arctic ground squirrels: effects of food and predation. J. Anim. Ecol. 66: 527-541.

Hughes, J.J., and Ward, D. 1993. Predation risk and distance to cover affect foraging behaviour in Namib desert gerbils. Anim. Behav. 46: 1243-1245.

Hughes, J.J., Ward, D., and Perrin, M.R. 1994. The effects of predation risk and competition on habitat selection and activity of gerbils in the Namib desert. Ecology, 75: 1397-1405.

Hurlbert, S.H. 1984. Pseudoreplication and the design of ecological field experiments. Ecol. Monogr. 54: 187-211.

Jennrich, R.I., and Turner, F.B. 1969. Measurement of non-circular home range. J. Theor. Biol. 22: 227-237.

Karels, T.J. 1996. Interactions between food and predation in limiting arctic ground squirrel populations. M.Sc. thesis, University of Toronto, Toronto, Ont.

Karels, T.J., Byrom, A., Boonstra, R., and Krebs, C.J. 2000. The interactive effects of food and predation on reproduction and overwinter survival of arctic ground squirrels. J. Anim. Ecol. 69: 235-247.

Keith, L.B. 1990. Dynamics of snowshoe hare populations. In Current mammalogy. Edited by H.H. Genoways. Plenum Press, New York. pp. 119-195.

Keith, L.B., and Cary, J.R. 1991. Mustelid, squirrel, and porcupine population trends during a snowshoe hare cycle. J. Mammal. 72: 373-378.

Keith, L.B., Todd, A.W., Brand, C.J., Adamcick, R.S., and Rusch, D.H. 1977. An analysis of predation during a cyclic fluctuation of snowshoe hares. In Proceedings of the 13th International Congress of Game Biologists, Atlanta, Ga., March 11-15, 1977. Edited by T.J. Peterle. Wildlife Society and Wildlife Management Institute, Washington, D.C. pp. 151-175.

Kidd, N.A.C., and Lewis, G. 1987. Can vertebrate predators regulate their prey? A reply. Am. Nat. 130: 448-453.

Klenner, W., and Krebs, C.J. 1991. Red squirrel population dynamics. I. The effect of supplemental food on demography. J. Anim. Ecol. 60: 961-978.

Korpimäki, E., and Norrdahl, K. 1991. Do breeding nomadic avian predators dampen population fluctuations of small mammals? Oikos, 62: 195-208.

Krebs, C.J. 1989. Ecological methodology. HarperCollins, New York.

Krebs, C. J., Keller, B.L., and Tamarin, R.H. 1969. Microtus population biology: demographic changes in fluctuating populations of $M$. ochrogaster and M. pennsylvanicus in southern Indiana. Ecology, 50: 587-607.

Krebs, C.J., Gilbert, B.S., Boutin, S., Sinclair, A.R.E., and Smith, J.N.M. 1986. Population biology of snowshoe hares. I. Demog- 
raphy of food-supplemented populations in the southern Yukon, 1976-1984. J. Anim. Ecol. 55: 963-982.

Krebs, C.J., Boonstra, R., Boutin, S., Dale, M., Hannon, S., Martin, K., Sinclair, A.R.E., Smith, J.N.M., and Turkington, R. 1992. What drives the snowshoe hare cycle in Canada's Yukon? In Wildlife 2001: populations. Edited by D.R. McCullogh and R.E. Barrett. Elsevier, London. pp. 886-896.

Krebs, C.J., Boutin, S., Boonstra, R., Sinclair, A.R.E., Smith, J.N.M., Dale, M.R.T., Martin, K., and Turkington, R. 1995. Impact of food and predation on the snowshoe hare cycle. Science (Washington, D.C.), 269: 1112-1115.

Lack, D. 1954. The natural regulation of animal numbers. Clarendon Press, Oxford.

Lima, S.L., and Dill, L.M. 1990. Behavioral decisions made under the risk of predation: a review and prospectus. Can. J. Zool. 68 : 619-640.

Manly, B.F.J. 1991. Randomization and Monte Carlo methods in biology. Chapman and Hall, London.

Marcström, V., Keith, L.B., Engren, E., and Cary, J.R. 1989. Demographic responses of arctic hares (Lepus timidus) to experimental reductions of red foxes (Vulpes vulpes) and martins (Martes martes). Can. J. Zool. 67: 658-668.

Mares, M.A., Lacher, T.E., Willig, M.R., Bitar, N.A., Adams, R., Klinger, A., and Tazik, D. 1982. An experimental analysis of social spacing in Tamias striatus. Ecology, 63: 267-273.

McLean, I.G. 1985. Seasonal patterns and sexual differences in the feeding ecology of arctic ground squirrels (Spermophilus parryii plesius). Can. J. Zool. 63: 1298-1301.

McNamara, J.M., and Houston, A.I. 1987. Starvation and predation as factors limiting population size. Ecology, 68: 1515-1519.

Menkens, G.E., and Anderson, S.H. 1988. Estimation of smallmammal population size. Ecology, 69: 1952-1959.

Michener, G.R. 1979. Yearly variations in the population dynamics of Richardson's ground squirrels. Can. Field-Nat. 93: 363-370.

Michener, G.R., and Michener, D.R. 1977. Population structure and dispersal in Richardson's ground squirrels. Ecology, 58: 359-368.

Murie, J.O. 1992. Predation by badgers on Columbian ground squirrels. J. Mammal. 73: 385-394.

O'Donoghue, M., Boutin, S., Krebs, C.J., and Hofer, E.J. 1997. Numerical responses of coyotes and lynx to the snowshoe hare cycle. Oikos, 80: 150-162.

O’Donoghue, M., Boutin, S., Krebs, C.J., Zuleta, G., Murray, D.L., and Hofer, E.J. 1998. Functional responses of coyotes and lynx to the snowshoe hare cycle. Ecology, 79: 1193-1208.
Otis, D.L., Burnham, K.P., White, G.C., and Anderson, D.R. 1978. Statistical inference for capture data from closed populations. Wildl. Monogr. No. 62. pp. 1-135.

Patterson, B.R., Banjamin, L.K., and Messier, F. 1998. Prey switching and feeding habits of eastern coyotes in relation to snowshoe hare and white-tailed deer densities. Can. J. Zool. 76: 1885-1897.

Pollock, K.H., Winterstein, S.R., Bunck, C.M., and Curtis, P.D. 1989. Survival analysis in telemetry studies: the staggered entry design. J. Wildl. Manage. 53: 7-15.

Pollock, K.H., Nichols, J.D., Browne, C., and Hines, J.E. 1990. Statistical inference for capture-recapture experiments. Wildl. Monogr. No. 107. pp. 1-97.

Rohner, C. 1994. The numerical response of great horned owls to the snowshoe hare cycle in the boreal forest. Ph.D. thesis, The University of British Columbia, Vancouver.

Sauer, J.R., and Williams, B.K. 1989. Generalised procedures for testing hypotheses about survival or recovery rates. J. Wildl. Manage. 53: 137-142.

Schmutz, J.K., and Hungle, D.J. 1989. Populations of ferruginous and Swainson's hawks increase in synchrony with ground squirrels. Can. J. Zool. 67: 2596-2601.

Schmutz, S.M., Boag, D.A., and Schmutz, J.K. 1979. Causes of the unequal sex ratio in populations of adult Richardson's ground squirrels. Can. J. Zool. 57: 1849-1855.

Sinclair, A.R.E. 1989. Population regulation of animals. In Ecological concepts. Edited by J.M. Cherrett. Blackwell Scientific Publications, Oxford. pp. 197-241.

Small, R.J., and Keith, L.B. 1992. An experimental study of red fox predation on arctic and snowshoe hares. Can. J. Zool. 70: 1614-1621.

Sokal, R.R., and Rohlf, F.J. 1995. Biometry. 3rd ed. W.H. Freeman and Co., New York.

Steenhof, K., and Kochert, M.N. 1988. Dietary responses of three raptor species to changing prey densities in a natural environment. J. Anim. Ecol. 57: 37-48.

Stuart-Smith, A.K., and Boutin, S. 1995. Predation on red squirrels during a snowshoe hare decline. Can. J. Zool. 73: 713-722.

Sutherland, W.J. 1988. Predation may link the cycles of lemmings and birds. Trends Ecol. Evol. 3: 29-30.

Taitt, M., and Krebs, C.J. 1981. The effect of extra food on small rodent populations. II. Voles (Microtus townsendii). J. Anim. Ecol. 50: 125-137. 